\title{
Improvement of the Curriculum to ensure the Accreditation and Globalization of the Mechatronics Engineering Program at Ricardo Palma University
}

\author{
Dra. Margarita Murillo \\ ${ }^{1}$ Ricardo Palma University, Perú, margarita.murillom@ ciplima.org.pe
}

\begin{abstract}
The present investigation determined that the update of the competences, the technological advances, the deadlines that the university law regulates and the standards of the accrediting entities contribute to the improvement of the curriculum ensuring the accreditation obtained and the inclusion in the global education of the mechatronics engineering, Faculty of Engineering (FI) at the University Ricardo Palma (URP). The stated objective explains that the professional profile of the graduate determines the relation of subjects, the number of hours and credits, as well as the adequate infrastructure of workshops and laboratories, allows the adequate development of the academic processes and that the properly selected competencies for each of the subjects guarantee the approach of relevant content. The theoretical reference is based on the concept of "Curriculum" of Glazman and Ibarrola (1978), who argue that the curricula can be organized by subjects, areas of knowledge or modules, any of the options implicitly has a conception of man, science, knowledge, practice, school-society relationship, learning and teaching, and professional practice. The study population corresponds to the Professional School of Mechatronic Engineering, School of Engineering of the URP. The results were evaluated with stadigraphs descriptive evaluation indicators and correspondence Hypothesis Test / Criterion p-value obtaining a p-value 0.039 which determines evaluate the dimensions of the study variables. These results showed positive effects on improving the curriculum to ensure national and international accreditation in 2023 of the curriculum mechatronics engineers. It is concluded that the improvement of the curriculum is based on the graduation profile, the relationship of the competences with the Curriculum, the lists of each subject, the methodological strategies, the learning evaluation system and the proposal of the new curriculum mesh.

Keywords- Curriculum, accreditation, globalization, skills, teaching- learning.
\end{abstract}

\section{INTRODUCTION}

Universities in Peru are governed by a legal framework established in three laws: the quality of education in [1] Policy Quality Assurance of Higher Education University in [2] and the System of Evaluation, Accreditation and Certification of Educational Quality in [3].

Within the legal framework, in 2017 the program of mechatronic engineering studies of the URP was accredited for six (06) years. This accreditation was met with the evaluation criteria and availability of the corresponding means of verification to the technical committee of national accreditation of engineering (CTAI) of the Institute for Quality and accreditation of Software, Engineering and Technology (ICACIT) and international accreditation by the agency accreditation Board for Engineering and Technology $(\boldsymbol{A B E T})$, entities recognized by the National System of

Digital Object Identifier (DOI):

http://dx.doi.org/10.18687/LACCEI2020.1.1.388

ISBN: 978-958-52071-4-1 ISSN: 2414-6390
Evaluation, Accreditation, and Certification of Educational Quality (SINEACE), and since then we are in a permanent self-evaluation for the purpose of Renewal of Accreditation adopting a culture of continuous improvement, since thanks to this process they are established mechanisms to ensure quality training program, evaluate the performance of each of the classes that make it up and improve continuously in all procedures, contributing to increased community satisfaction and developing competitive advantages that allow us to obtain recognition at national and international level again in 2023.

In support of the research, thesis, articles and scientific journals have been reviewed as [4] Accreditation as an instrument for continuous improvement in higher education, [5] Technical guidance to the self-assessment process for the purpose of renewal of accreditation of the mechanical engineering program, [6] Quality assurance of engineering education through accreditation: The impact of Engineering Criteria 2000 and its global influence, [7] Curriculum alignment, globalization, and quality assurance in South African higher education and [8] The Bologna Process, globalization and engineering education developments.

To demonstrate the hypothesis an experimental group was used, to which the training and the survey were applied to demonstrate that the improvement of the curriculum will ensure the assurance of the accreditation and globalization of the mechatronics engineering program at the URP.

Besides, the results of this research will serve as the basis for the Office of Academic Development, Quality and Accreditation to urge the different URP programs that basic curricular principles be reconsidered in light of emerging educational needs and that the concepts that should receiving particular attention are curricular alignment, globalization and quality assurance.

\section{ESTATE OF ART}

The URP is constituted among other faculties by the engineering faculty with 5 professional schools: civil, computer, electronic and industrial, all nationally and internationally accredited for 6 years. The mechatronic engineering program is a young program with 13 years of operation, has had its first national and international accreditation in 2017 for 6 years that will be renewed in 2023, and must comply with the standards of the ICACIT accreditation entities and ABET.

In this regard, to ensure accreditation and globalization of the program mechatronics among other definitions [9] explains that the curriculum is instrumental synthesis by which they are selected, organized and arranged for teaching 
purposes, all aspects of a profession that is considered socially and culturally valuable, professionally efficient. At the same time [9] considers that the plan should have a rationale derived from the formal curriculum, from which emanates the organization of all the elements that comprise it, such as the description of the purpose of the race or educational level, a time duration of careers, organization by quarters, semesters or annuals, structuring by subjects, areas or modules, specification of general and specific objectives of each subject, area or module, number of hours of theory and practice of each subject, area or module, compulsory, optional and total credits, social service specifications, options, and qualification requirements. The accreditation obtained was the act by which the State made public the recognition of the quality of the mechatronics engineering program, which voluntarily underwent a rigorous evaluation to demonstrate compliance with the standards in the training of its future professionals. Currently, the program is evaluating its processes with feedback actions and necessary adjustments through a continuous quality improvement circuit, evaluating the inputs, processes, context, results and social impact, for the purposes of reacredit and certification.

The referential that supports the concept of quality applied to higher education institutions is [10] that defines quality as the term of reference that allows comparing an institution or program with other homologates or around a predetermined real or utopian pattern, whose component or dimensions may be the relevance, integrity, effectiveness, availability of human, material and information resources, efficiency, effectiveness and management of academic and administrative processes.

A very important aspect of the accreditation is that by comparing the mechatronic engineering program with other internationally approved programs, it inserts us into globalization, in this regard [11] it describes that globalization is covering all areas of human activity: production of goods, finance, market, research and, of course, higher education, because its impact on the new social complexity is mainly manifested in an accelerated restructuring of the labor market, in the expansion and diversification of the structure of the education system itself higher. Likewise, [11] he maintains that the great challenge for academic programs is that training alternatives be increased, and the conditions prioritized so that new generations learn to learn for themselves faster. should no longer be the one-way transmission of knowledge from the teacher to the student; The training should be the result of intense interaction between educator and educator, which will force the teacher to assume the responsibility of permanently enriching their own knowledge so that they can go to the forefront of change, which does not exclusively obey developments technologically, but also to the greater specialization and diversification of science.

On globalization [11] the following is mentioned: a) universities must be open to society. All subjects offered should be considered learning opportunities for anyone who wants to take them, without further requirement; b) achieve, by agreement of the University Council, that 30 or $35 \%$ of the credits of all the degrees are free for the students; c) establish a category of free students not attached to any career, school or faculty that can take the subjects they want, the last name of the degree of these students would be put at the end, not at the beginning of their studies and d) open exams and transparent for each subject. If the student passes the exam, credits will be assigned without having taken the class.

In this regard [12] he insists on fighting for the freedom to teach and the freedom to learn and make students increasingly responsible for their own training and become autonomous learners. For [12] academic rigidity has terrible consequences; among others: a) generates attrition; b) prevents innovation; c) there is no place for interdisciplinary and d) it creates an irresponsible system because teachers are not free to teach or students to learn [...]; the initiative that is later reflected in society is killed, where everyone expects to be told what they have to do. Our universities do not generate leaders, but employees; e) they are not able to respond with the opportunity to the changing conditions of society and labor markets and f) makes society and parents think that the only careers that are worthwhile are the traditional ones.

As indicated by [11] and [12] globalization is currently understood as global education or international education and characterizes the tendency to include in the curriculum topics, thematic nuclei or globalized issues related to contents of global interest that are studied, from an interdisciplinary perspective with an international vision, such as energy, the environment, engineering, human rights, racism, and others. A holistic vision of education for the training of engineers integrates three main axes: the object of the profession and the training of professional skills, the scientific approach to the solution of professional problems and the ethical training of the contemporary engineer.

From the elements described above, the essential features that should characterize the engineer as a professional, based on the study of international engineering trends and national and international experience.

Regarding the professional profile [13], he considers that the engineer must have a deep knowledge of the basic, specific sciences and the profession, capable and independent and with solid general theoretical and scientific training. Being a professional who is closely linked to the industry, acquired during its preparation in college, basic vocational skills that will allow solving the most general and frequent problems of their social environment. Being a more comprehensive, versatile and flexible professional whose fundamental virtue is its capacity for self-preparation and adaptation to changes, which requires paying special attention to aspects such as the development of its communication, management, processing, and use of information capacity scientific-technical, with mastery of computing, knowledge of foreign languages, economic, ecological and humanistic training in general. Possessing a cultural formation capable of developing human relationships, which requires professional, social, environmental knowledge, updated information, values and feelings, professional ethics and selfesteem. Having logical thinking, heuristic, scientific, systemic, able to model their ideas, flexible to adapt to changes quickly. Therefore, and taking into account the complexities in which reality is presented and manifested today, engineering education must incorporate the interdisciplinary approach in the analysis and treatment of the problems that arise. The Engineering profession for being so close to solving practical problems requires an academic background in the increasingly interdisciplinary, comprehensive, scientific, practical, social and humanistic 
professionals. This will be possible, to the extent that their scientific, technological, ecological, social, ethical training is perfected, among others.

For [13] the conception of the 21st-century engineer represents a paradigm shift. Today's engineer must be a participant in his creation; you should not look for work, but create it; It must have a comprehensive, world-class training, with a broad perspective and vision of national and world realities; leader, entrepreneurial spirit, able to work in a team and above all committed to their social environment, with ethical principles and with a clear notion of the common good.

Targeted elements required to provide the college student a set of skills or skills that allow you to face the future, according to [13] characterizes seven (7) categories:

1. Independent and interdependent learning skills for life.

2. Critical and creative thinking skills for problem-solving.

3. Skills or competencies for interpersonal work and teamwork.

4. Communication skills.

5. Skills to express judgments and capacity for self-judgment (evaluation and self-evaluation).

6. Integration of disciplinary knowledge.

7. Ability to handle change.

The performance of engineering professionals in the companies where they work, according to [14], requires creativity, autonomy, flexibility in a changing environment, leadership capacity, versatility, high development potential, good communication, work, and team management, negotiation and decision making. It is possible to reach the pointed elements if the engineering curriculum considers the following basic characteristics:

1. Prevalence of the formative component over the informative that considers the solidity in the formation in basic sciences: Mathematics, Physics, Chemistry and Informatics with the aim of learning to learn for life.

2. Specific training in an engineering branch with sufficient quantity and quality of knowledge to respond to the objective of learning to do.

3. Necessary additional training in areas of economics, languages, social and administration whose objective is to learn to be.

In that sense, [15] defines the general profile that the engineer of the year 2020 must possess:

1. Create environments in which the design and promotion of learning activities and situations favor the development of the intellectual potential of individuals.

2. Develop the ability to face reality in a reflexive, critical and constructive way, with large doses of autonomy and selfdetermination.

3. Fully identify the transversal axes that affect the most problematic or socially relevant situations in the area, place, country, region or the world.

4. Develop the ability to face problems with their ingenuity of the engineer with the ability to act in an interrelated and interdisciplinary way.

5. Acquiring the ability to learn to learn to enable it to successfully face the changing situation of reality and adapt quickly and innovatively, to the problems that arise.
To achieve the above in the engineer's training it is required:

1. The organization of the educational process centered on the student-focused on what he needs to learn and not on what teachers want to teach.

2. An educational teaching process that is characterized by being interactive and collaborative, under the guidance of the teacher, with the use of methods and procedures that allow developing a set of skills, abilities, and modes of action that allow the professional to anticipate and interact with reality and Provide solutions in your social environment.

3. A lifelong learning and commitment of educational institutions university to give those opportunities.

\section{METHODOLOGY}

The Mechatronics Engineering Program is a career that has 13 years of providing quality educational services. This quality was evaluated with the national and international accreditation obtained in 2017 by the ICACIT and ABET accreditors respectively, entities recognized by SINEACE.

From 2017 to date, the evaluation matrices have been updated regarding the criteria and standards that we must meet in 2023, seeking the renewal of the mechatronics engineering program accreditation, for which the FI-URP has established policies of continuous improvement considering the accreditation process emanating from SINEACE, which is indicated in Figure 1.

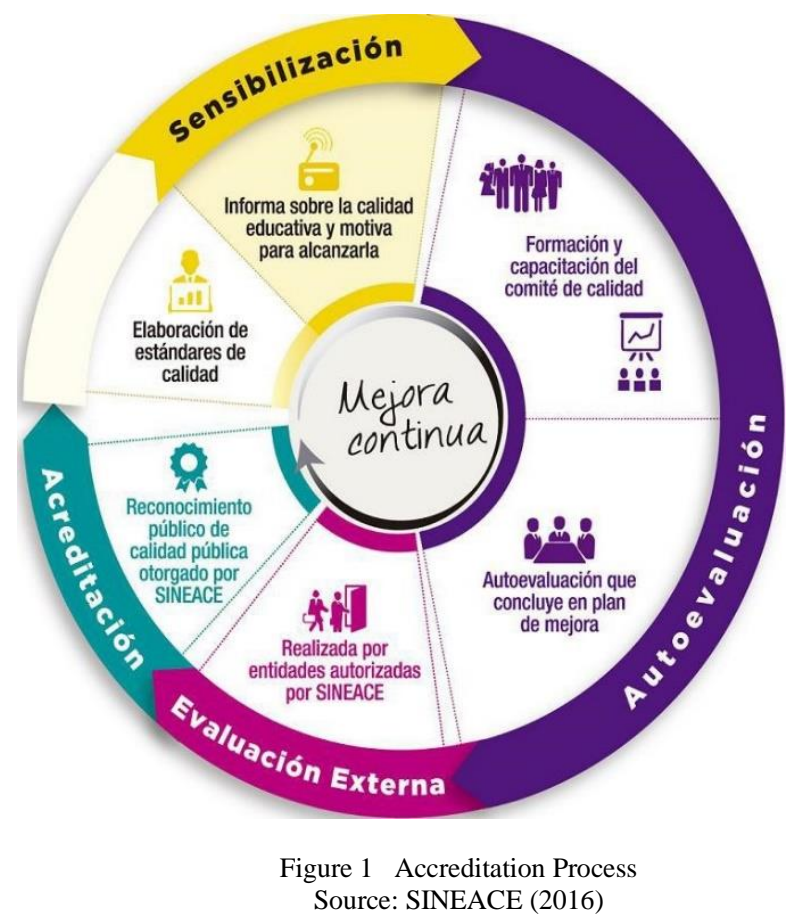

The need to update the curriculum is enriched from the observations given in the accreditation processes experienced in 2017. To improve processes, stakeholder participation must be encouraged, otherwise, the quality will not drive. In addition to dividing the process into three important parts, it is argued that the quality of education can be achieved through: 
1. Teaching team. The teacher must share the project of institutional quality, assume the roles that correspond to play and work on common objectives.

2. Teamwork or quality circles. The purpose of the team is to make decisions and act accordingly. However, the multiple responsibilities assumed by the teacher, in many cases, prevent them from working in this way.

For the investigation, the sample formed by the Curriculum Evaluation Commission of the Mechatronics Engineering Program named Decree Resolution No. 0052019-FI-dated May 17, 219-URP was considered. The members were 4 , added to 4 members of the other engineering programs making a total of 16 teachers within which were the directors of each program.

Likewise, it was considered a sample of 25 Teachers, 30 students from different cycles, 15 graduates and 8 employers, all of the mechatronics engineering program to whom the research instrument was applied.

\section{Methodology to follow}

The improvement of the curriculum began with the training modules by the Office of Academic Development, Quality and Accreditation (ODACA).

The training was carried out permanently assessing the participation of the different commissions who collaborated on common issues developed by the engineering programs. The schedule, modality and contents of the training are shown in Table I.

TABLE I

TRAINING SCHEDULE

\begin{tabular}{|c|c|c|c|c|c|}
\hline ITEM & DATE & HOUR & PLACE & DETAILS & CONTENTS \\
\hline \multirow{2}{*}{1} & \multirow{2}{*}{ 16-Set-19 } & 08:00-09:00 & \multirow{2}{*}{ Auditorium B } & Conference & \multirow{2}{*}{$\begin{array}{l}\text { Graduate profile by } \\
\text { competences }\end{array}$} \\
\hline & & $09: 00-12: 30$ & & Workshop & \\
\hline \multirow{3}{*}{2} & \multirow{3}{*}{ 30-Set-19 } & 08:00-09:00 & \multirow{3}{*}{ Auditorium B } & Conference & \multirow{3}{*}{$\begin{array}{l}\text { Relationship of } \\
\text { competencies with the } \\
\text { Curriculum }\end{array}$} \\
\hline & & $09: 00-11: 30$ & & Workshop & \\
\hline & & $11: 30-12: 30$ & & Exposicion & \\
\hline \multirow{2}{*}{3} & \multirow{2}{*}{ 14-Oct-19 } & 08:00-09:00 & \multirow{2}{*}{$\begin{array}{l}\text { Degrees } \\
\text { Room }\end{array}$} & Conference & \multirow{2}{*}{ Methodological strategies } \\
\hline & & $09: 00-12: 30$ & & Workshop & \\
\hline \multirow{2}{*}{4} & \multirow{2}{*}{ 21-Oct-19 } & 08:00-09:00 & \multirow{2}{*}{$\begin{array}{l}\text { Degrees } \\
\text { Room }\end{array}$} & Conference & \multirow{2}{*}{$\begin{array}{l}\text { Learning Evaluation } \\
\text { System }\end{array}$} \\
\hline & & 09:00 - 12:30 & & Workshop & \\
\hline \multirow{2}{*}{5} & \multirow{2}{*}{ 28-Oct-19 } & 08:00-09:00 & \multirow{2}{*}{$\begin{array}{l}\text { Degrees } \\
\text { Room }\end{array}$} & Conference & \multirow{2}{*}{ Curriculum alignment } \\
\hline & & $09: 00-12: 30$ & & Workshop & \\
\hline \multirow{2}{*}{6} & \multirow{2}{*}{ 4-Nov-19 } & 08:00-09:00 & \multirow{2}{*}{$\begin{array}{l}\text { Degrees } \\
\text { Room }\end{array}$} & Conference & \multirow{2}{*}{$\begin{array}{l}\text { Presentation and support } \\
\text { of the proposal }\end{array}$} \\
\hline & & $09: 00-12: 30$ & & Workshop & \\
\hline
\end{tabular}

Fuente: ODACA (2019)

The recommendations for the construction of the profile are based on 4 points, as shown in Figure 2.

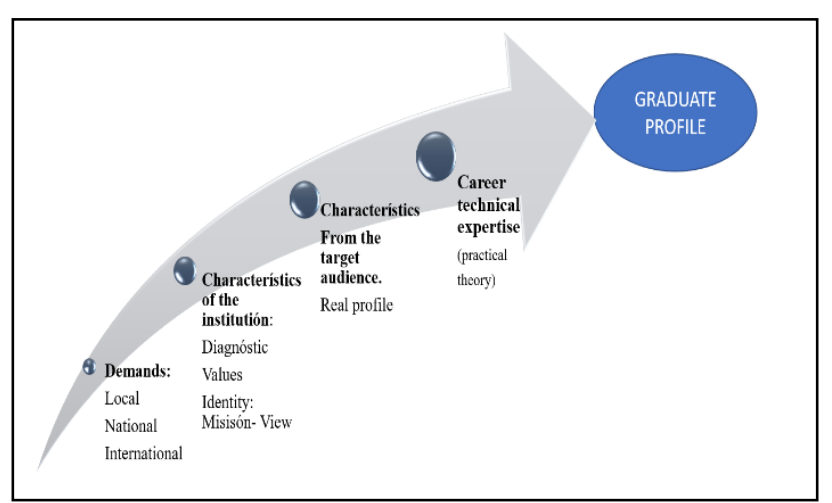

Figure 2 Sources for the construction of the Egress Profile Source: Capacitation ODACA (2019)
After the training, the curriculum evaluation commission of the mechatronics engineering program developed the proposal for the improvement of the curriculum based on each of the contents of the training.

1. Graduate Profile - in this regard, the research instrument based on the survey applied to Teachers, Students, Graduates and Employers related to Specific and Generic Competencies, Current Curriculum and Curriculum was developed.

2. Globalization - Benchmarking was applied to universities in the QS ranking between nationals and foreigners that offer the Mechatronics Engineering program.

3. The LC-01-19 Checklists and LC-02-19 Checklists were prepared

4. The characterization of the Curriculum Plan was developed

5. The conclusions and recommendations to be considered for the improvement of the curriculum that will be applied in the 2020-2 cycle were issued.

6. The proposal of actions framed in the pedagogical model approved by University Council Agreement $\mathrm{N}^{\circ} 0343$ 2019 was made

Finally, the proposed curriculum was developed considering:

a. Graduate profile-generic and specific competences

b. Alignment of competencies with the subjects of the current curriculum

c. Indicators of the relationship of competencies with the plan by basic, intermediate and advanced level

d. Analysis of the curricular alignment and proposal of the new plan.

The contents were written according to the competences, methodological strategies, learning assessment system as well as the development of the syllable for the subject of Basic Mechatronics Engineering Workshop, which will be validated during the 2020-1 cycle

From the analysis carried out above, it can be inferred that the improvement of the curriculum is based on the graduation profile, the relationship of the competences with the Curriculum, the submissions and explains that the professional profile of the graduate determines the relationship of subjects, number of hours and credits and that the properly selected competencies for each of the subjects ensure the presentation of relevant contents.

\section{RESULTS}

This section presents the analysis of the results of the improvement of the curriculum to renew the accreditation and globalization of the program of mechatronic engineering of the URP.

\section{Application of the survey research instrument:}

From graph 1, it is observed that of the total of the sample, $32 \%$ are Teachers and work in the Mechatronics Program at the URP, 38\% are students of mechatronics of the URP, 19\% are graduated from Mechatronics of the URP of which 2 work as teachers in other universities and 13 work in different companies and $10 \%$ represent the companies in which our graduates work, being some of the the manager's mechatronics engineers of the URP. 
TABLE II

SAMPLE BY OCCUPATION AND LABOR CENTER

\begin{tabular}{|c|c|c|c|c|c|}
\hline \multirow{2}{*}{ OCCUPATIÓN } & \multicolumn{3}{|c|}{ LABOR CENTER } & \multirow{2}{*}{ Frecuency } & \multirow{2}{*}{ Percent } \\
\hline & URP & ANOTHER UNIV & BUSINESS & & \\
\hline Teacher & 25 & & & 25 & $32 \%$ \\
\hline Student & 30 & & & 30 & $38 \%$ \\
\hline Graduated & & 2 & 13 & 15 & $19 \%$ \\
\hline Employer & & & 8 & 8 & $10 \%$ \\
\hline TOTAL & 55 & 2 & 21 & 78 & $100.00 \%$ \\
\hline
\end{tabular}

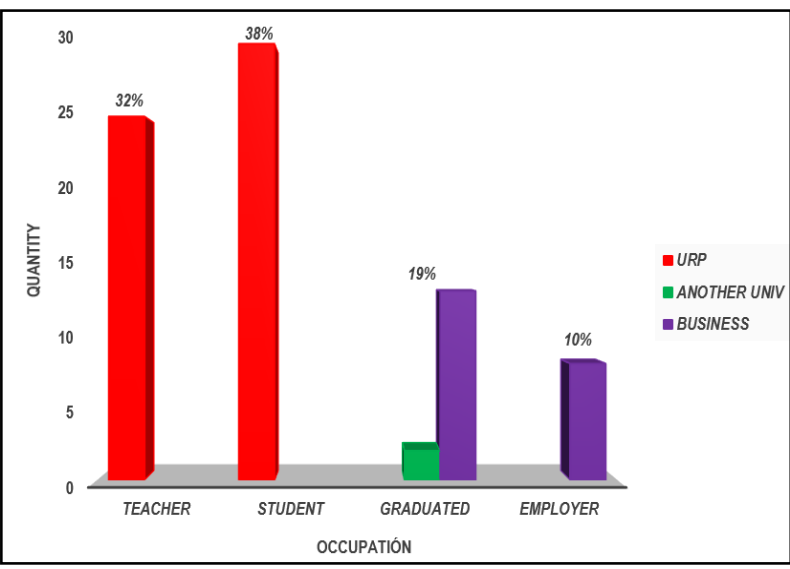

Graphic 1 Sample by occupation and labor center.

Source: Own elaboration (2019)

The survey presents closed and open questions with answers on the licker scale (strongly agree, agree, disagree, strongly disagree), to consider in the improvement of the plan the perception of the different members of the community of the URP mechatronic engineering program.

Table III shows the closed questions of the survey 1-3-5-7-910-11-13 and 14 .

TABLE III

DIMENSIONS FOR IMPROVING THE CURRICULUM

\begin{tabular}{|c|c|}
\hline DIMENSION & QUESTION \\
\hline DEGREE PROFLE & 1 Profle of the graduate of Mechatronics Engineering is in line with the demands of the labor market \\
\hline $\begin{array}{c}\text { GENERIC } \\
\text { COMPETENCES }\end{array}$ & $\begin{array}{l}3 \text { The generic competences that the Mechatronics Engineering graduate must reach are in accordance with } \\
\text { the demands of the labor market }\end{array}$ \\
\hline $\begin{array}{c}\text { SPECIFC } \\
\text { COMPETENCES }\end{array}$ & $\begin{array}{l}5 \text { The specifc competences that the Mechatronics Engineering graduate must reach are in accordance with } \\
\text { the demands of the labor market }\end{array}$ \\
\hline LABORFELD & 7 The labor feld established in the Curriculum is in line with current technological advances \\
\hline $\begin{array}{l}\text { CURRICULAR } \\
\text { PLAN }\end{array}$ & $\begin{array}{l}9 \text { The subjects of the Curiculum Plan respond to the needs of the graduation profle } \\
10 \text { The subjects of the Basic Studies Program (PEB) are suitable for the achievement of the generic } \\
\text { competences of the career } \\
11 \text { Specialy subjects are suitable for the achievement of specifc career competencies }\end{array}$ \\
\hline CURRICULUN & $\begin{array}{l}13 \text { The established curriculum mesh is consistent with the requirements of each subject of the Curriculum } \\
14 \text { The curiculum presents the relevant academic areas for mechatronic engineering }\end{array}$ \\
\hline
\end{tabular}

From Table III and Graph 2, it is observed that questions $1,3,5,7,9,11,13$ and 14 have significant percentage levels Agree in response and with very low percentage levels Disagree, this allows us to infer that we must make specific adjustments to our Curriculum Plan.

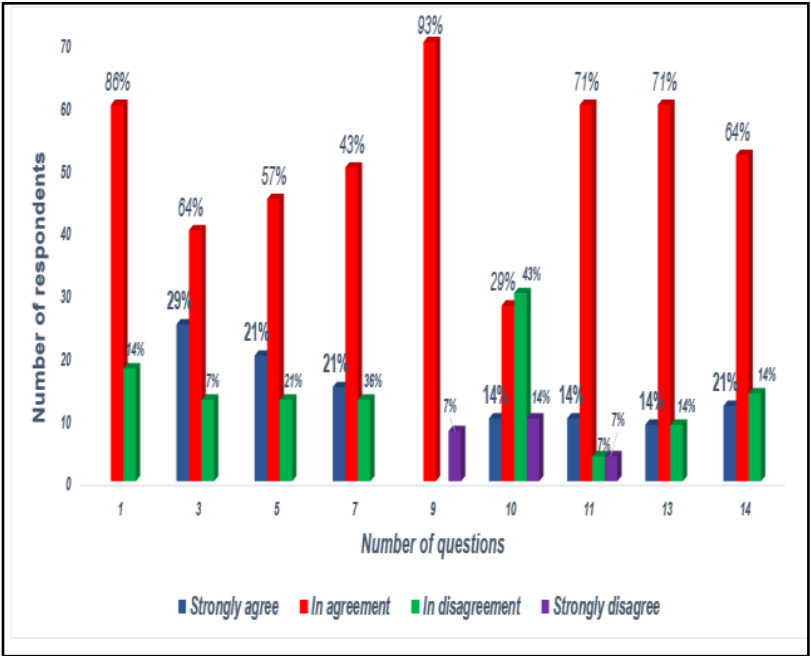

Graphic 2 Responses to the dimensions of the plan. Source: Own elaboration (2019)

Table IV shows the open questions of the survey 2-4-68-12 and 15.

TABLE IV

DIMENSIONS FOR IMPROVING THE CURRICULUM

\begin{tabular}{|c|c|}
\hline DIMENSION & QUESTION \\
\hline DEGREE PROFILE & $\begin{array}{l}\text { Suggestions for improving the graduate profile: } \\
\text { (Consider the subjects of the curriculum) }\end{array}$ \\
\hline $\begin{array}{c}\text { GENERIC } \\
\text { COMPETENCES }\end{array}$ & 4 Suggestions to improve generic skills \\
\hline $\begin{array}{c}\text { SPECIFIC } \\
\text { COMPETENCES }\end{array}$ & 6 Suggestions to improve specific skills \\
\hline LABOR FIELD & 8 Suggestions for the Labor Field \\
\hline $\begin{array}{l}\text { CURRICULAR } \\
\text { PLAN }\end{array}$ & 12 Suggestions for improving curriculum \\
\hline CURRICULUM & 15 Suggestions for the Curriculum \\
\hline
\end{tabular}

Source: Own elaboration (2019)

Graphic 3 Contributions to improve the curriculum

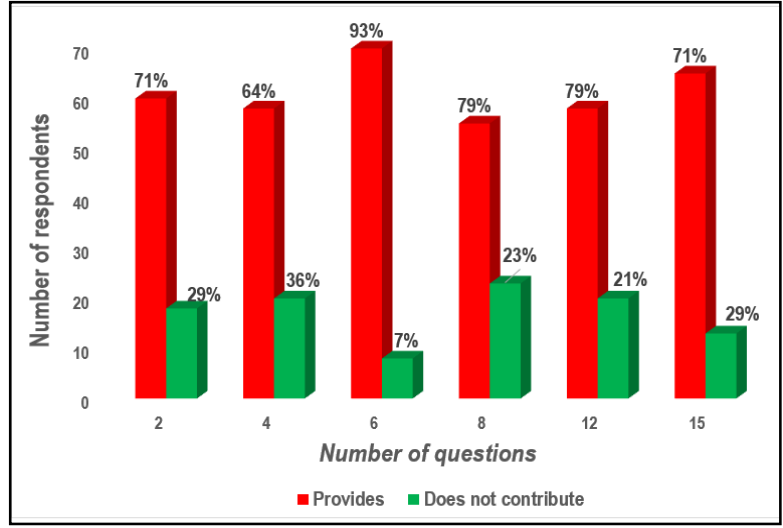

Source: Own elaboration (2019)

From Table III and Graph 1, it can be seen that questions $2,4,6,8,12$, and 15 have significant percentage levels of suggestions, in response and with very low percentage levels who did not contribute, this allows us to infer that we should consider the contributions collected for our Curriculum Plan.

The contributions referred to the questions in Table IV are shown in Table $\mathrm{V}$. 
TABLE V

CONTRIBUTIONS TO IMPROVE THE STUDY PLAN

\begin{tabular}{|c|c|c|}
\hline DIMENSION & & CONTRIBUTIONS \\
\hline DEGREE PROFLE & 2 & $\begin{array}{l}\text { Consider Microcontrollers, modern programming, internet of things (industry 4.0). Remove from } \\
\text { the profile the subjects Signal Processing and biomedical. Focus on the subjects innovation and } \\
\text { development. }\end{array}$ \\
\hline $\begin{array}{c}\text { GENERC } \\
\text { COMPETENCES }\end{array}$ & 4 & Many skills, specify. Focus on finance and related subjects. Additional training in soft skills \\
\hline $\begin{array}{c}\text { SPECLFC } \\
\text { COMPETENCES }\end{array}$ & 6 & $\begin{array}{l}\text { Consider the industry in the modern world as the Internet of things and Artificial Intelligence. The } \\
\text { student's programming skills should be better consolidated. It must be consistent with ABET } \\
\text { criteria. They do not consider Signal Processing and Biomedical. Include Mechatronics in heavy } \\
\text { machinery, Development, automation, project management and SAP Course. }\end{array}$ \\
\hline LABORFELD & 8 & $\begin{array}{l}\text { Indicate more labor fields such as bioengineering, control engineering, etc. Currently, the new } \\
\text { paradigm is Industry } 4.0 \text {. Change Robotics to Industrial Robotics. Eliminate Signal Processing } \\
\text { and biomedical. Include Maintenance and Installation of Industrial Machines. Consider for the } \\
\text { profle the logistics sector, mining, construction, food industries, etc. }\end{array}$ \\
\hline $\begin{array}{l}\text { CURPCULAR } \\
\text { PLAN }\end{array}$ & 12 & $\begin{array}{l}\text { Consider the subject of intelligent systems control as mandatory. The curriculum is related to the } \\
\text { labor field. }\end{array}$ \\
\hline CURRCULUM & 15 & $\begin{array}{l}\text { Include logical and analytical skills in students. Promote the use of modern technologies and } \\
\text { improve laboratory equipment. Restructure the academic areas. Replace the subject of } \\
\text { Communications Engineering with Sensors and Actuators, PLC, SCADA, Servomotors, MES and } \\
\text { ERP. In addition to pre-professional practices, consider internships in companies in the field. } \\
\text { Consider the presentation of a thesis or thesis project that has been developed in the workplace. }\end{array}$ \\
\hline
\end{tabular}

1. Application of Benchmarking to the universities of the QS ranking, regarding globalization.

TABLE VI

SELECTED UNIVERSITIES OF THE QS RANKING

\begin{tabular}{clc}
\hline UNIVERSITY & \multicolumn{1}{c}{ NAMES } & ACRONYM \\
\hline \multirow{4}{*}{ NATIONALS } & Ricardo Palma University & URP \\
& National University of Engineering & UNI \\
& University of Engineering and Technology & UTEC \\
& Peruvian University of Applied Sciences & UPC \\
& Pontifical Catholic University of Peru & PUCP \\
\hline \multirow{3}{*}{ INTERNATIONAL } & National University of Colombia- Bogota & UNC \\
& Batangas State University - Pilipinas & BSU \\
& University of Malaga - Spain (4 year career) & UM $^{*}$ \\
\hline
\end{tabular}

Source: Own elaboration (2019)

From these Universities the following comparison indicators have been taken, regarding the URP: Subjects, Number of Credits and Complementary Activities, the results of which are shown in the following tables:

TABLE VI

SUBJECT INDICATORS

\begin{tabular}{|c|c|c|c|c|c|c|c|c|}
\hline \multirow{2}{*}{ ASIGNATURAS } & \multicolumn{5}{|c|}{ NATIONALS } & \multicolumn{3}{|c|}{ INTERNATIONAL } \\
\hline & URP & UNI & UTEC & UPC & PUCP & UNC & BSU & UM" \\
\hline 1. Total number of subjects & 65 & 70 & 70 & 53 & 60 & 60 & 75 & 50 \\
\hline 2. Average number of courses per semester & 6.5 & 7 & 7 & 5.3 & 6 & 6 & 7.5 & 6.5 \\
\hline 3. Number of compulsory subjects & 60 & 67 & 57 & 47 & 54 & 42 & 75 & 38 \\
\hline 4. Number of elective subjects offered & 22 & 34 & 0 & 0 & 56 & 20 & 0 & 40 \\
\hline 5. Number of elective subjects required & 5 & 3 & 13 & 6 & 6 & 8 & 0 & 12 \\
\hline 6. Number of subjects with a requirement & 49 & 38 & 0 & 25 & 22 & 24 & 30 & 0 \\
\hline 7. Number of subjects with two requirements & 1 & 13 & 0 & 13 & 12 & 4 & 18 & 0 \\
\hline 8. Number of subjects with more than two requ & 0 & 0 & 0 & 0 & 6 & 0 & 3 & 0 \\
\hline 9. Number of research subjects & 4 & 4 & 4 & 4 & 4 & 3 & 2 & 3 \\
\hline 10. Number of propaedeutic subjects of General Studies & 15 & 12 & 0 & 9 & 26 & 0 & 0 & 10 \\
\hline
\end{tabular}

Source: Own elaboration (2019)

The EPIM-URP Curriculum, concerning the total number of subjects, is on average concerning the other Universities. Regarding the number of subjects with a requirement, we have a higher value than the other universities, so we infer that the requirements to take a subject of the following cycle must be reviewed, improving this component will increase the number of subjects that have two requirements. Regarding the other components compared, it is observed that our Curriculum is within the standards considered by the Universities that are in the QS Ranking.
TABLE VII

CREDITS INDICATORS

\begin{tabular}{|l|c|c|c|c|c|c|c|c|}
\hline \multirow{2}{*}{ CREDITS } & \multicolumn{4}{|c|}{ NATIONALS } & \multicolumn{1}{|c|}{ INTERNATIONAL } \\
\cline { 2 - 10 } & URP & UNI & UTEC & UPC & PUCP & UNC & BSU & UM \\
\hline 1. Average Credits per Semester & 20 & 21.4 & 20.2 & 20 & 19 & 17.9 & 23.2 & 30 \\
\hline 2. Total number of credits of compulsory subjects & 185 & 205 & 152 & 182 & 173 & 126 & 232 & 120 \\
\hline 3. Total number of credits of elective subjects & 15 & 9 & 50 & 18 & 17 & 53 & 0 & 48 \\
\hline 4. Total number of credits of PEB subjects & 29 & 5 & 18 & 21 & 14 & 18 & 28 & 10 \\
\hline 5. Total number of credits of research subjects & 13 & 8 & 12 & 14 & 16 & 13 & 13 & 12 \\
\hline $\begin{array}{l}\text { 6. Number of credits of propaedeutic subjects of General } \\
\text { Studies }\end{array}$ & 35 & 39 & 0 & 35 & 84.25 & 0 & 0 & 60 \\
\hline
\end{tabular}

Regarding the semiannual credits, credits of compulsory subjects and the total credits of elective subjects we are in the average, which gives us a margin of variability to improve our Curriculum.

Regarding the number of credits of the PEB, the URP has $33 \%$ of credits, while the national universities are $6 \%$ to $23 \%$.

TABLE VIII

INDICATORS OF COMPLEMENTARY ACTIVITIES

\begin{tabular}{l|c|c|c|c|c|c|c|c|}
\hline \multirow{2}{*}{ COMPLEMENTARY ACTIVITIES } & \multicolumn{4}{c|}{ NATIONALS } & \multicolumn{3}{c|}{ INTERNATIONAL } \\
\cline { 2 - 10 } & URP & UNI & UTEC & UPC & PUCP & UNC & BSU & UM $^{*}$ \\
\hline 1. Language level required of the end of the race & Basic & Basic & hitermediate & Basic & Basic & hitermediate & Basic & Basic \\
\cline { 2 - 10 } $\begin{array}{l}\text { 2. Number of academic events and conferences required } \\
\text { 3. Number of hours for National Defense Seminar }\end{array}$ & 40 & 0 & 0 & 0 & 0 & 0 & 0 & 0 \\
\cline { 2 - 10 } & 0 & 0 & 0 & 0 & 0 & 0 & 0 & 0 \\
\hline
\end{tabular}

Source: Own elaboration (2019)

Regarding complementary activities such as English language and academic events, national and foreign universities do not consider it in their Curriculum, an indicator that requires us to review these activities.

\section{Graduate profile of the mechatronic engineering program}

Design projects related to Mechatronics Engineering to manage automated industrial processes, control and robotics integrating the scientific, technological and humanistic areas.

TABLE IX

COMPETENCES OF THE GRADUATE OF MECHATRONICS

\begin{tabular}{|c|c|c|}
\hline \multicolumn{3}{|c|}{ COMPETENCES } \\
\hline INSTITUTIONAL & GENERIC & SPECIFIC \\
\hline $\begin{array}{l}\text { C1: Ethical behavior: } \\
\text { Pemonstrates behavior in accordance with } \\
\text { nniversal ethical principles TO promote } \\
\text { pood citzen coexistence ACTNG at the } \\
\text { eervice of people and sociely. }\end{array}$ & $\begin{array}{l}\text { G1: Troubleshooting: } \\
\text { Idenffes formulates and solves complex } \\
\text { engineering problems by applyng the } \\
\text { principles of engineening, science and } \\
\text { mathematcs, to solve them judiciously and } \\
\text { effectively. (E) }\end{array}$ & $\begin{array}{l}\text { E1: Mechatronics Engineering Projects: } \\
\text { Designs projects related to Mechatronics Engineering to } \\
\text { manage automated industrial procosses integrafing } \\
\text { scienfifc, technological and humanistc areas }\end{array}$ \\
\hline $\begin{array}{l}\text { 22: Critical and Creative Thinking: } \\
\text { Analyzes the products and processes of } \\
\text { heir work to propose creative solutions to } \\
\text { roblems APPRECIATING the knowledge } \\
\text { end innovation at the service of society }\end{array}$ & $\begin{array}{l}\text { 62: Communication } \\
\text { It communicates effectively with a variely of } \\
\text { audiences, for the good professional } \\
\text { development (G) }\end{array}$ & $\begin{array}{l}\text { E2: Implementation of Mechatronic Systems } \\
\text { Implements mechatronic yystems, equipment and devices } \\
\text { FOR applicabons in Agro-industry, Medicine, Energy, } \\
\text { Mining, Fisheries and industry in general APPLYING } \\
\text { opdimally control techniques, microprocessors, } \\
\text { microcontrollers, computers, sensors and automation. }\end{array}$ \\
\hline \multirow[t]{3}{*}{$\begin{array}{l}\text { C3: Shared Leadership: } \\
\text { tpromotes the cooperation of people TO } \\
\text { echieve a shared vision, } \\
\text { DEMONSTRATING autonomy, } \\
\text { esponsibility and commitment in social } \\
\text { tansformation. }\end{array}$} & $\begin{array}{l}\text { Q3: Teamwork } \\
\text { Effectively work in teams whose members } \\
\text { together provide leadership, create a } \\
\text { collaborative and inclusive environment, set } \\
\text { goals, plan tasks and meet goals. (G) }\end{array}$ & $\begin{array}{l}\text { E3: Engineering Design } \\
\text { Apply engineering design TO achieve innovafive solutions } \\
\text { SATISFYYNG specific needs taking into account public } \\
\text { health, safely and well-being, as well as global, cultural, } \\
\text { economic, environmental and social lactors }\end{array}$ \\
\hline & $\begin{array}{l}\text { 64: Learning and Professional } \\
\text { Development: } \\
\text { Acquire and apply new knowedge as } \\
\text { necessary, using appropriate learning } \\
\text { strategies, to adapt to new stuatons. (G) }\end{array}$ & $\begin{array}{l}\text { E4: Experimentation: } \\
\text { Develops, appropriate experiments to draw relevant } \\
\text { conclusions by analyzing data using engineering judgment. }\end{array}$ \\
\hline & & $\begin{array}{l}\text { E5: Equipment Maintenance } \\
\text { Provides Mechatronic Equipment Maintenance service } \\
\text { FOR is correct operafion in the industry APPLYNG modem } \\
\text { predictive, prevenfive and corrective maintenance } \\
\text { techniques. }\end{array}$ \\
\hline
\end{tabular}

Source: Mechatronics Program (2019)

$\mathbf{1 8}^{\text {th }}$ LACCEI International Multi-Conference for Engineering, Education, and Technology: "Engineering, Integration, and Alliances for a Sustainable Development "Hemispheric Cooperation for Competitiveness and Prosperity on a Knowledge-Based Economy", 29-31 July 2020, Buenos Aires, Argentina. 6 
2. Relationship of Competences with the Curriculum In order to obtain the relationship of competences with the Plan Table X, it was determined that the following levels:

A - BASICS
B - INTERMEDIATES
C - ADVANCED

TABLE $X$

RELATIONSHIP OF COMPETENCES WITH THE STUDY PLAN

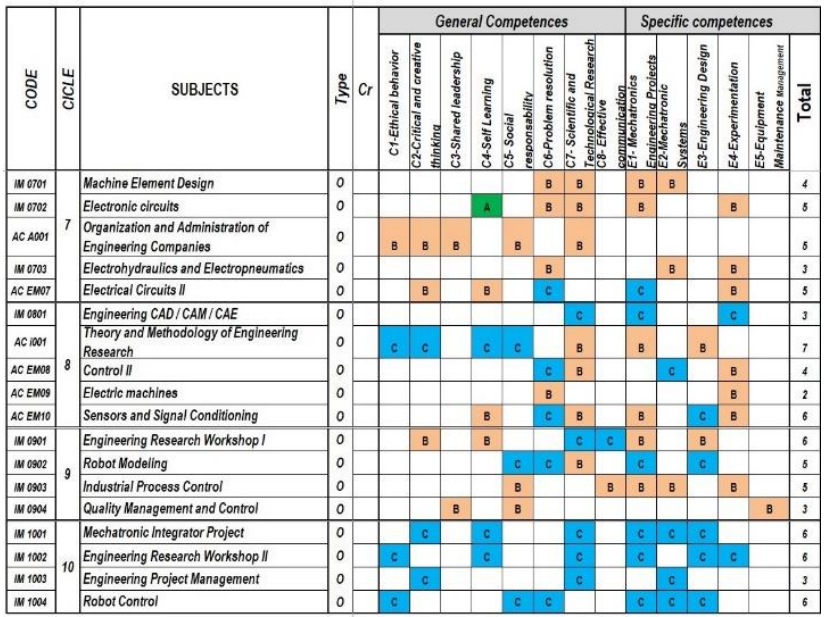

Source: Own elaboration (2019)

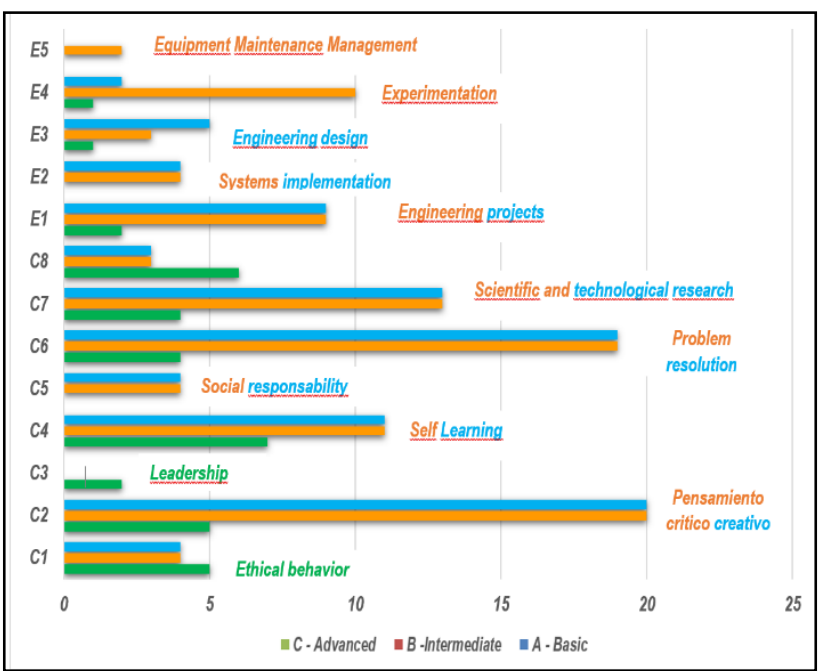

Figure 3: Results of the relationships with the plan Source: Own elaboration (2019)

\section{CONCLUSIONS}

The background has made it possible to delimit the approach of the problem regarding the variables of the improvement of the Curriculum to ensure the accreditation and globalization of the mechatronics engineering program whose results validate the present investigation.

In turn, the study variables are supported by theorists in whom we have referenced for the support of this research

The results obtained from the current 2015-II plan will be improved through the application of the survey, benchmarking, profile and competency indicators of the mechatronics engineering graduate, whose criteria are indicated in the tables and statistics of the corresponding graphs.

Regarding the competences in the curriculum, as shown in Figure 3, the following was considered for the improvement of the plan:

A. Include subjects or content in the Basic Level that develop general skills such as:

Critical and creative thinking

Self-Learning

Problem resolution

Investigation scientific and technological

Experimentation

B. Include subjects or content in the Intermediate and Advanced Level that develop general skills such as:

Ethical behavior

Leadership

Effective communication

Regarding specific competences:

C. Include subjects or contents in the Intermediate and Advanced Level that develop specific competencies such as:

Engineering designs

Systems implementation

Experimentation

Maintenance management

Also, include content for the competition Management of equipment maintenance in the subjects of Management and Quality Control and Manufacturing Processes

Propose two (02) subjects related to Equipment Maintenance Management in the 7th and 8th cycles.

\section{ACKWLEDGMENTS}

Specially and sincerely to my colleagues and executives of the URP who contributed with their valuable suggestions, constructive criticism, moral and intellectual support to crystallize the present investigation.

To my family, for their unconditional support and permanent help in my personal and professional training.

\section{REFERENCES}

[1] Ley 28044 Ley General de Educación (LGE), "la calidad educativa", Lima, Perú, 2007.

[2] Ley Universitaria 30220-DS 016-2015- MINEDU "Política de Aseguramiento de la Calidad de la Educación Superior Universitaria “, Lima, Perú, setiembre 2015.

[3] Ley 28740, "Ley del Sistema Nacional de Evaluación, Acreditación y Certificación de la Calidad Educativa”, Lima, Perú, 2016

[4] J. Solís, tesis "La acreditación como instrumento de mejora continua en educación superior", Universidad Autónoma de Nuevo León México- 2017

[5] S. Marcela, tesis "Direccionamiento técnico al proceso de autoevaluación con fines de renovación de acreditación del programa de ingeniería mecánica" Universidad Industrial de Santander Bucaramanga, Colombia, 2006

[6] J. Prados and G. Peterson and L. Lattuca article "Quality assurance of engineering education through accreditation: The impact of Engineering Criteria 2000 and its global influence", Journal of Engineering, Volume 94, Issue 1, January 2005, University of Tennessee USA.

[7] R. McDonald and H. Van Der Horst, article "Curriculum alignment, globalization, and quality assurance in South African higher education", Journal of Curriculum Studies, Mar 2007

[8] J. Uhomoibhi, article "The Bologna Process, globalization and engineering education developments", Vol. 3 No. 4, pp. 248-255, November 2009 
[9] R. Glazman, and M. Ibarrola, "Diseño de planes de estudio", México. CISE. UNAM, 1978, p.13.

[10] Instituto Internacional de la UNESCO - (IESALC), "Informe sobre la Educación Superior en América Latina y el Caribe 2000-2005, la metamorfosis de la educación superior", Segunda edición digital: 250 ejemplares Caracas, Enero 2007.

[11] A. Acosta, " Poder y políticas de educación superior en América Latina. Perfiles Latinoamericanos, dic. 2000, no. 17, p.81.

[12] R. Diaz de Cossío, "Flexibilizar la educación superior Mexicana," tendencias y opiniones", octubre 2001, no. 127, pp. 54-56.

[13] R. Smith, "La formación científica del ingeniero para el año 2020", ISBN: 978-958-680-054-9 Marzo 2007, Bogotá D.C. Colombia.

[14] C. Palma, "Nuevos retos para el ingeniero en el siglo XXI". Revista semestral de ingeniería e innovación de la Facultad de Ingeniería, Universidad Don Bosco, Junio - Noviembre, 2 (4). pp. 61-65. 2012

[15] Oramas, J. (2007). El perfil del ingeniero del año 2020.

[16] Moreno, I. "Consideraciones para una enseñanza de calidad en ingeniería”, Revista Pedagogía Universitaria, Vol. XII, No. 1, pp. 38 46, 2007

\section{BIOGRAPHY}

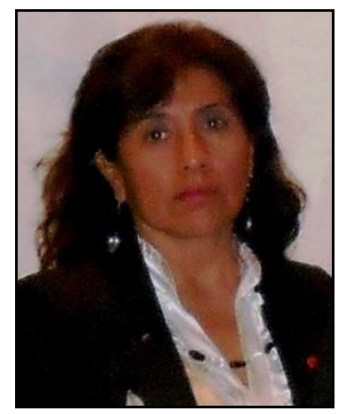

Margarita Murillo Manrique. She is a Doctor in Education, master's in teaching and Educational Management and Electrical Engineer.

She works as a Professor at the Ricardo Palma University (URP) - Professional School of Mechatronics Engineering. She served as Dean of the Faculty of Engineering and Management and as director of the Professional School of Electrical Mechanical Engineering at the National Technological University of South Lima - UNTELS.

She works as an ordinary teacher at the UNTELS - Professional School of Electrical Mechanical Engineering.

She was an advisor and instructor in the Department of Education at the School of Communications of the Army of Peru - COEDE - Ministry of Defense.

She has an honorary doctorate from Daniel Alcides Carrion University. Recognition of the College of Engineers of Peru.

SCOPUS -TRAINING IN TELEMATIC ENGINEERING FOR PROFESSIONAL PERFORMANCE IN ENGINEERING SERVICES AT THE CENTER OF TELEMATICS OF THE ARMY OF PERU. Proceedings of the 17TH LACCEI International Multi-conference for Engineering, Education and Technology. Número/Volumen: : \#466 . (DOI): http://dx.doi.org/10.18687/LACCEI2019.1.1.466 ISBN: 978-0-9993443-6-1 ISSN: 2414-6390
"IMPACT OF RENEWABLE ENERGIES ON DISTRIBUTED GENERATION SYSTEMS"- Publication in PAIDEIA XXI Postgraduate Magazine URP-ISSN: 2221 - 7770 V 5 No 4 December 2013. DOI: https://doi.org/10.31381/paideia.v4i5

<http://revistas.urp.edu.pe/index.php/Paideia/article/view/923>

"INTELLIGENT FACILITIES IN THE RATIONAL USE OF ELECTRICAL ENERGY"- Publication in PAIDEIA XXI Postgraduate Magazine URP-ISSN: 2221 - 7770 V 4 N $\mathrm{N}^{\circ} 4$ August 2014 DOI: https://doi.org/10.31381/paideia.v3i4.936

<http://revistas.urp.edu.pe/index.php/Paideia/article/view/923>

"STRATEGIES TO MARKET RENEWABLE ENERGIES IN THE PERUVIAN ELECTRIC MARKET" - Publication in Engineering Profiles Journal of the Faculty of Engineering URP-ISSN: 1996 - 660/ V 13 N 13 July 2017. DOI: https://doi.org/10.31381/perfiles_ingenieria.v13i13 <http://revistas.urp.edu.pe/index.php/Paradigmas/article/view/1493>

SISTEMA DE COMUNICACIÓN INDUSTRIAL PARA EL MONITOREO DE LAS ESTACIONES DE ESTACIONES DE ÁGUA POTABLE EN CIENEGUILLA-LIMA. Publicación Revista de la Facultad de Ingeniería. PERFILES DE INGENIERÍA / ISSN 1996-6660 Año XIV, № 14, 2018 pp. 145157.

DOI: https://doi.org/10.31381/perfiles ingenieria.v14i14.2378

"SISTEMA DE COMUNICACIÓN INDUSTRIAL PARA EL MONITOREO DE LAS ESTACIONES DE ESTACIONES DE ÁGUA POTABLE EN CIENEGUILLA-LIMA”. Publicación Revista de la Facultad de Ingeniería. PERFILES DE INGENIERÍA / ISSN 1996-6660 Año XIV, Nº 14,2018 pp. $145-157$. DOI: https://doi.org/10.31381/perfiles ingenieria.v14i14.2378

She has developed the following research as a member: "Implementation of a Solid Waste Management Plan in UNTELS”.

She has presented as author the following research: "Clean Energy System taking advantage of diffuse radiation from the sun with polycrystalline photovoltaic cells for alternating and continuous current loads in the Mechanical and Electrical Engineering Laboratory providing energy efficiency at UNTELS".

She is a methodological teacher for the development of thesis. He is a jury in the thesis support. Permanently advises the development of specialty projects.

It develops projects in the area of electrical installations in medium and low voltage.

Areas of interest: Intelligent electricity networks, Distributed generation, Energy audit, Inmotic, informatics and networks. 